\title{
Earthquake Damage Repair Loss Estimation in New Zealand: What Other Variables Are Essential Based on Experts' Opinions?
}

\author{
Ravindu K. A. V. D. Kahandawa ${ }^{1, *}$ C, Niluka D. Domingo ${ }^{1}$, Gregory Chawynski ${ }^{1}{ }^{\oplus}$ and S. R. Uma ${ }^{2}$ \\ 1 School of Built Environment, Massey University, Auckland 0632, New Zealand; \\ n.d.domingo@massey.ac.nz (N.D.D.); G.Chawynski@massey.ac.nz (G.C.) \\ 2 GNS Science, Lower Hutt 5040, New Zealand; S.Uma@gns.cri.nz \\ * Correspondence: R.kahandawa@massey.ac.nz; Tel.: +64-2041388771
}

\begin{abstract}
Major earthquakes can cause extensive damage to buildings and alter both the natural and built environments. Accurately estimating the financial impact from these events is complex, and the damage is not always visible to the naked eye. PACT, SLAT, and HAZUS are some of the computer-based tools designed to predict probable damage before an earthquake. However, there are no identifiable models built for post-earthquake use. This paper focuses on verifying the significance and usage of variables that specifically need to be considered for the post-earthquake cost estimation of earthquake damage repair work (CEEDRW). The research was conducted using a questionnaire survey involving 92 participants who have experience in cost estimating earthquake damage repair work in New Zealand. The Weighted Average, Relative Importance Index (RII), and Exploratory Factor Analysis were used to analyse the data. The research verified that eleven major variables that are significant to the CEEDRW and should be incorporated to cost estimation models. Verified variables can be used to develop a post-earthquake repair cost estimation tool and can be used to improve the pre-earthquake loss prediction tools.
\end{abstract}

Keywords: New Zealand; cost estimation; earthquake damage repairs; variables

\section{Introduction}

Earthquakes are naturally occurring, unpredictable hazards that could cause a considerable amount of damage to communities and their economies. From 1980 to 2018, 115 catastrophic earthquake and tsunami events caused 806,134 fatalities, US $\$ 885$ billion in overall losses, and US \$119 billion in insured losses [1]. Japan, China, United States, and New Zealand have been some of the world's latest most prominent victims at considerable cost [1]. For example, it is estimated that rehabilitation after the 2010-2011 Canterbury earthquake sequence (CEQS) in New Zealand required NZ \$40 billion and NZ \$21 billion in insured losses [2,3]. Some of the recovery work of CEQS continued even in 2019. Since a singular event can cause a considerable impact on a country and its insurance sector, an accurate estimation of the financial impact of repairing buildings after an earthquake is imperative.

The repair cost is one of the vital factors deciding if the property is repaired or rebuilt [4]. There were many previous studies conducted on earthquake disaster modelling. Performance-based earthquake engineering (PBEE) framework-based FEMA P-58 methodology and regional damage evaluation and estimation using GIS are some of the prominent methodologies used for earthquake damage predictions [4,5]. Based on this, PACT, SLAT, HAZUS and, SP3 tools were developed to estimate the; repair time, repair cost, casualties or injuries, and safety placarding [6-8]. These tools were developed to predict the probable damage from future earthquakes and reduce future damage to buildings by improving the performance of building elements $[4,9,10]$. Other research further improved these processes using methods like seismic community resilience modelling, 3D scan-based damage 
mapping, 3D element visualisation, and productivity sequencing [11-13]. However, these tools have limitations related to the cost estimation process like non-consideration of; the impact of time duration on cost estimations, price escalations due to demand surge, the current state of the building, and aftershocks [14]. The aforementioned limitations prevent these tools from producing more accurate repair cost estimates $[5,15]$, which are required for post-earthquake cost estimation. Therefore, there is an opportunity to improve the cost estimation processes for these tools.

One main reason for discrepancies between construction cost estimates produced by computer modelling tools and the final building repair cost is that multiple variables impact the estimated construction cost. Non-consideration of such variables is one reason for cost overruns [16]. There has been much research into variables influencing cost variations in construction projects [16-20]. The impact of these variables differs based on the project type.

During the post-earthquake stage, there are exceptional variables that impact costs. Previous research has noted eleven such variables that specifically impact earthquake damage scenarios [21]. The existence and impact of some of these variables are further discussed in the next section.

\section{Variables Considered in Current Cost Estimation Models}

Previous research has suggested that most of the variables affecting earthquake damage repair work are considered in post-earthquake repair cost estimations. However, unforeseeable damage, occupancy during repair, and aftershocks' impact are the only three variables considered by current cost estimation tools. However, the impact of occupancy during repair work was only used for time estimation and not for the cost estimation process [14]. The impact of aftershocks and earthquake-induced hazards is also partially included in the models. Nevertheless, compared with post-earthquake damage estimation, P-58 methodology-based models have the advantage as they include unforeseen probable damage based on past and experimental data. However, earthquake cost estimates produced from these models will never match the actual value and will likely never get to that point. However, a post-earthquake cost estimation model should consider the impact of these variables. Therefore, the following Table 1 synthesis the variables in detail with their impact on the project cost.

Table 1. Variables impacting CEEDRW.

\begin{tabular}{l}
\hline \multicolumn{1}{c}{ Variable } \\
\hline $\begin{array}{l}\text { Consequential damage } \\
\text { repair (F 01) }\end{array}$
\end{tabular}

Cost of professional services (F 02)

Varying profit margins depending on the type of building contract $(\mathrm{F}$ 03)
Depending on the risk, the profit of the contractor will vary, thus changing the construction costs.
Elements in buildings are interconnected. For example, damaged hot water cylinders, brick chimneys, Damage to one element might cause damage to other elements. Additional damage can also occur during repair work.

The cost of professional services in construction is generally related to; design, architectural, and engineering fees (D/A/E). However, if the repair work is funded by insurance, legal fees can come into play. and brick parapet walls had caused damage to other elements like; roof structure, roof tiling, canopies, plumbing, electrical services, and other building elements during CEQS [22,23].

A study was carried out in Italy on repairs conducted for 5775 residential buildings after the 'L'Aquila earthquake identified that professional fees for D/A/E services could be as high as $16 \%$ to $17 \%$ of the total cost [24]. However, the professional fees did not include legal fees.

A fixed-price contract will assign this risk to a contractor allowing no changes of price. On the other hand, cost-plus-profit contracts could assign the client's risk, which pays all the contractor's costs plus profit [25].

According to a New Zealand court case [26], the average profit margin on repairs CEQS was identified as 10 percent, which can vary according to the required specialised skills and changes risk [27]. 
Table 1. Cont.

\begin{tabular}{l}
\hline \multicolumn{1}{c}{ Variable } \\
\hline \\
Restrictions during \\
repair work (F 04)
\end{tabular}

Aftershocks, earthquake-induced hazards and weather conditions (F 05)

Price fluctuations after an earthquake (F 06)

Repair time (F 07)

Initially unforeseen damage (F 08)

Changes to the final repair state $(\mathrm{F} 09)$
Repair work of a building might be restricted due to it being occupied during construction [15]. Restrictions would result in additional work, increasing the cost and repair time.

Other than significant shaking, earthquakes create aftershocks, liquefaction, tsunamis, seiches, fire, inundation, and landslides [29]. These can create additional damage to buildings.

Buildings that have had their external fabric compromised might be damaged further by normal weather conditions like rain, wind, and snow [30]. Earthquake damages create a sudden need to repair or rebuild based on the demand for construction-related goods and services. The sudden imbalance between supply and demand can increase the cost of construction. This dynamic price fluctuation occurring after an earthquake is defined as a demand surge [35].

Demand surge and annual price fluctuations will affect the price of construction-related goods. The start date will, therefore, determine applicable rates of construction. Therefore, it will be considered under price fluctuations. Repair time is inter-dependent on the cost of a project [42]. Repair time can be separated into duration and start date.

Duration of repair work can be prolonged by variables like building occupancy during construction and resource availability [15].

Initially, unforeseen damages are concealed earthquake damage. For example, structural columns, foundations, and services such as electrical and plumbing work are uncovered usually through destructive testing or during repair work $[43,44]$.

In any construction work, the cost of construction will be related to the required final output. The final state of repairs may differ from pre-earthquake or as-built conditions during post-earthquake repair work. Changes can be instigated by building code or main stakeholders-building owners and insurance claim providers.
Preventive measures are required to restrict access to the whole building and protect occupants from health and safety issues. For example, daily cleaning, covering of working areas, temporary pathways, and construction work restrictions are few measures.

Additionally, Ward et al. [28] verified that repair time and cost would be higher in occupied buildings.

Damage from post-earthquake liquefaction, aftershock [31], fire [32], and flooding [33] have also been identified after the CEQS. Damage from liquefaction is typically considered earthquake damage and considered in cost estimation models. However, the cause of damage from aftershocks, fire, and inundation requires additional evaluations to prove their direct causation from an earthquake [34]. Furthermore, building elements like; plasterboard, furniture, and electrical services can easily be damaged if the building interior is exposed to prolonged weather conditions.

Evidence of price inflation after a disaster can be seen in New Zealand [36,37], the United States of America [38,39], and China [40].

The start date of repair work is affected by the time required to acquire; long-lead equipment, post-earthquake building inspections, finance, engineering input for repair work, building permits, and suitably qualified builder [41]. There has been much research on estimating demand surge [38,39]. However, there is no known reference for its usage in construction projects.

Repair duration has a direct relationship to preliminary item cost that impact the overall project. Although duration estimation methods are available in P-58 based models [15], these are not linked to the cost estimation process.

Uncovering additional damage can lead to changes in cost estimates which become apparent during rehabilitation work after CEQS [45]. P-58 methodology is capable of predicting damage from an earthquake [15]. Therefore, the P-58 methodology can be used as a method to determine the extent of earthquake damage. However, due to the probabilistic nature of this methodology, estimations can vary.

According to previous research, changes in the final required state or design changes may affect final repair costs [20,46-48]. Furthermore, different cost estimations are required for any changes in the final repair state. 
Table 1. Cont.

\begin{tabular}{|c|c|c|}
\hline Variable & Description & Impact \\
\hline $\begin{array}{l}\text { Pre-earthquake state of } \\
\text { the building (F 10) }\end{array}$ & $\begin{array}{l}\text { Pre-earthquake conditions may not } \\
\text { reflect as-built drawings. Such deviations } \\
\text { can occur due to damage sustained } \\
\text { before an earthquake (such as historical } \\
\text { subsidence), inadequate construction } \\
\text { work and substandard repair work. }\end{array}$ & $\begin{array}{l}\text { These pre-earthquake damage is not covered by earthquake } \\
\text { insurance-funded repair work [49]. However, } \\
\text { pre-earthquake damage may also need to be repaired to } \\
\text { meet statutory requirements if it is required. Therefore, } \\
\text { additional inspections and separate cost estimations may be } \\
\text { required as part of the scope to repair that will not be } \\
\text { covered by insurance. Insurance claims-based repair work } \\
\text { can have substantial impact. For example, the insurance loss } \\
\text { reported by the CEQS was NZ } \$ 21 \text { billion, which was more } \\
\text { than } 52 \% \text { of the total loss [3]. }\end{array}$ \\
\hline $\begin{array}{l}\text { Substandard repair } \\
\text { work (F 11) }\end{array}$ & $\begin{array}{l}\text { Large-scale repairs were conducted after } \\
\text { each earthquake and can often be } \\
\text { repaired below the required standard. }\end{array}$ & $\begin{array}{l}\text { Cretney [50], Price and Peters [51] agreed that substandard } \\
\text { repair work was prominent after the CEQS. Substandard } \\
\text { repair work creates additional problems, including hidden } \\
\text { damage, repetitive work such as finishing work, demolition, } \\
\text { secondary damage identification, and potentially further } \\
\text { damage to the building due to comprised } \\
\text { structural integrity. }\end{array}$ \\
\hline
\end{tabular}

Even though a significant amount of evidence on variables impacting general construction cost, only one previous research was able to cumulate and identify the variables impacting CEEDRW through exploratory study [52]. However, the impacts of those variables post-earthquake CEEDRW were not verified. This research focuses on verifying the usage of variables in CEEDRW and identifying the significance of each on CEEDRW.

\section{Materials and Methods}

This research focuses on verifying the usage of aforementioned eleven variables (F01-F11) on CEEDRW and identifying the significance of each on CEEDRW, based on professional opinion (refer Table 2). A questionnaire survey was the data collection method used. The questionnaire survey was chosen as the most suitable method of data collection as it allowed acquiring a high number of respondents in a short period.

Table 2. Variables considered in the research.

\begin{tabular}{ll}
\hline Variable ID & \\
\hline F 01 & Consequential damage repair \\
F 02.1a & Cost of structural engineering services \\
F 02.1b & Cost of geotechnical engineering services \\
F 02.1c & Cost of land surveying services \\
F 02.2 & Cost of architectural services \\
F 02.3 & Cost of quantity surveying services \\
F 02.4a & Cost of lawyers' / advocates' legal services \\
F 02.4b & Cost of dispute resolution facilitators' / dispute resolvers' services \\
F 03 & Varying profit margins depending on the type of building contract \\
F 04 & Restrictions during repair (e.g., building being occupied during repair work) \\
F 05.1 & Damage from aftershocks \\
F 05.2a & Damage from earthquake-induced hazards-flood \\
F 05.2b & Damage from earthquake-induced hazards-fire \\
F 05.3 & Damage from weather conditions \\
F 06 & Price fluctuations due to change in demand for resources caused by an \\
F 07 & earthquake \\
F 08 & Duration of repairs \\
F 09.1 & Initially unforeseen damage \\
F 09.2 & Changes required to final repair state-to meet statutory compliance \\
F 10 & Changes required to final repair state-to meet stakeholder requirements \\
F 11 & Pre-earthquake state of the building \\
\hline
\end{tabular}




\subsection{Questionnaire Design}

The questionnaire survey contained three sections. The first section of the questionnaire was designed to acquire details of participants, specifically experience in CEEDRW. However, no names of the participants were collected to allow them to be anonymous. Only participants with experience in CEEDRW were considered for the study. The second section was used to verify if these variables were considered cost estimation during repair work related to the Canterbury earthquake and which should be used in future CEEDRW. The third section aims to identify the significance of the variables affecting CEEDRW using the five-point Likert scale (Five being very important and one being not important at all). Refer to Figures A1-A4 in Appendix A for a sample of the questionnaire design.

\subsection{Sampling Method and Data Collection}

The questionnaire survey targeted professionals with experience in CEEDRW in New Zealand who were hard to identify. Purposive sampling method can be used for highly relevant and specialised populations that are difficult to reach [53,54]. Therefore, the purposive sampling method was used for the questionnaire survey distribution. As the most likely professionals involved, the questionnaire was first distributed through the monthly newsletter to all NZIQS members (The New Zealand Institute of Quantity Surveyors), who were the main contributors to CEEDRW. The NZIQS newsletter only yielded four responses making the response rate less than $0.2 \%$. Because of the low response rate, online directories and databases on cost estimators and builders were used to sending 310 emails engaged via email and telephone reminders. Later, the survey yielded 94 replies with a $30.3 \%$ response rate. Both methods yielded 98 responses. Based on the information provided in section one of the questionnaire, six respondents were excluded from the data set as they did not have experience in CEEDRW. From the remaining 92 participants (refer to Figure 1), almost half of the participants had more than five years of experience in CEEDRW.

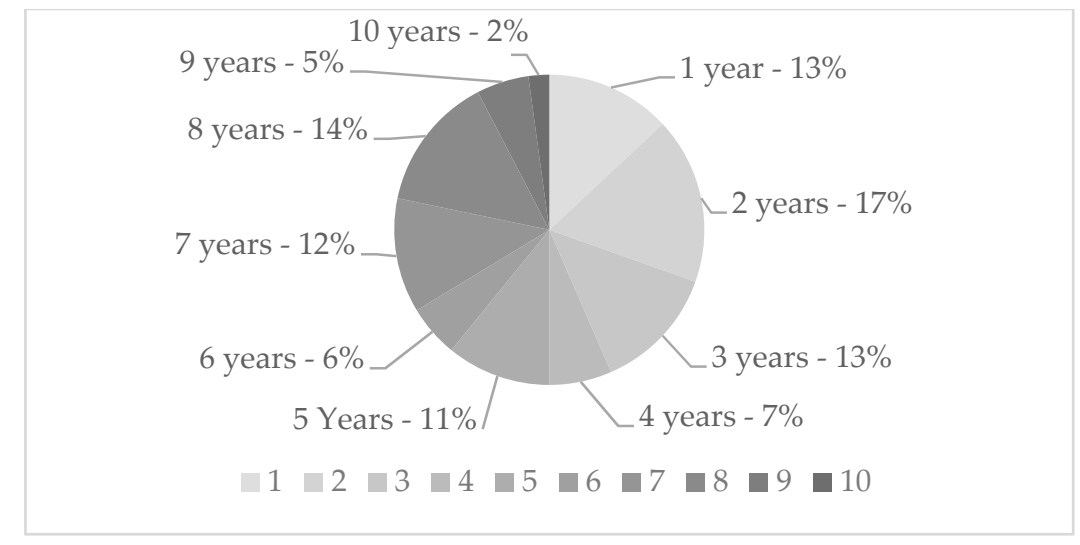

Figure 1. Years of experience in estimating the cost of earthquake damage repair work.

\subsection{Validity and Reliability}

The validity and reliability of the research method ensure the credibility and dependability of the research output. The validity of the research methods focuses on the proper design of the questionnaire that will accurately fulfill the objectives [55]. The validity of a questionnaire was evaluated in different areas such as construct validity, content validity, predictive validity, and face validity. However, the required validity methods depend on the aims of the research. Description of each validity and method of achieving is mentioned in Table 3. The data collection process was also approved by the Massey University Human Ethics Committee: Northern (Application 4000017232), which would also improve the validity of the research. 
Table 3. Method of achieving the required validity of the research.

\begin{tabular}{|c|c|c|}
\hline Type of Validity & Description & Method of Achievement \\
\hline Content validity & $\begin{array}{l}\text { Does the questionnaire cover } \\
\text { the required scope? }\end{array}$ & $\begin{array}{l}\text { Questions were developed based on a } \\
\text { literature review and reviews from } \\
\text { costing professionals. }\end{array}$ \\
\hline Construct validity & $\begin{array}{l}\text { Do questions achieve the } \\
\text { intended measurement? }\end{array}$ & $\begin{array}{l}\text { Qualitative. The questions for the } \\
\text { questionnaire were directly interpreted } \\
\text { from the hypothesis. Furthermore, five } \\
\text { cost estimation professionals validated } \\
\text { the questionnaire and objective with } \\
\text { experience in CEEDRW in the } \\
\text { pilot survey. }\end{array}$ \\
\hline Predictive validity & $\begin{array}{l}\text { Ability to make accurate } \\
\text { predictions from the data } \\
\text { collected? }\end{array}$ & $\begin{array}{l}\text { The research did not intend to achieve } \\
\text { predictive validity. Not knowing the } \\
\text { population and use non-random } \\
\text { sampling prevents achieving. }\end{array}$ \\
\hline Face validity & $\begin{array}{l}\text { Evaluation with non-experts } \\
\text { to check the understanding? }\end{array}$ & $\begin{array}{l}\text { Achieved by giving the questionnaire to } \\
\text { three non-experts in the pilot survey } \\
\text { for comments. }\end{array}$ \\
\hline
\end{tabular}

\subsection{Research Bias}

Even though many measures were used to improve validity and reliability, this research contains some research bias. These are selection bias, convivence bias, volunteer bias, non-response bias, response bias and wording bias. Details related to each type of bias are summarised in Table 4.

Table 4. Types of Bias related to the research.

\begin{tabular}{|c|c|c|}
\hline Type of Bias & Description & Reason of Unavoidability \\
\hline Selection bias & $\begin{array}{l}\text { Occurs when sample does not } \\
\text { represent the population }\end{array}$ & $\begin{array}{l}\text { The population could not be clearly } \\
\text { identified; thus random sampling could } \\
\text { not be used. }\end{array}$ \\
\hline Convivence bias & $\begin{array}{l}\text { Occurs when participants } \\
\text { were selected based on } \\
\text { convivence }\end{array}$ & $\begin{array}{l}\text { The types of respondents required for the } \\
\text { study were specialised and hard to find. } \\
\text { Therefore, purposing sampling was used } \\
\text { This method would lead to some forms of } \\
\text { convivence-based respondent selection. }\end{array}$ \\
\hline Volunteer bias & $\begin{array}{l}\text { Occurs when participants are } \\
\text { people who volunteer }\end{array}$ & $\begin{array}{l}\text { Since the study cannot be forced, } \\
\text { respondents had to be volunteers. }\end{array}$ \\
\hline Non-response bias & $\begin{array}{l}\text { Occurs when invited } \\
\text { respondents did not respond }\end{array}$ & $\begin{array}{l}\text { Since the study was voluntary, there were } \\
\text { potential respondents that did not } \\
\text { respond to the request. Even if } \\
\text { participants were reminded several times, } \\
\text { there were instances where this could not } \\
\text { be avoided. }\end{array}$ \\
\hline Response bias & $\begin{array}{l}\text { Participants change the } \\
\text { responses because they want } \\
\text { to change the outcome }\end{array}$ & $\begin{array}{l}\text { Participants were requested to be true, } \\
\text { but each respondent has the ability to } \\
\text { deviate from the truth. Furthermore, } \\
\text { respondents tend to provide positive } \\
\text { feedback rather than the truth. }\end{array}$ \\
\hline Wording bias & $\begin{array}{l}\text { Occurs through inaccurate } \\
\text { wording or leading questions }\end{array}$ & $\begin{array}{l}\text { Inaccurate wording or leading questions } \\
\text { were reduced through the pilot survey. } \\
\text { However, there could be residual } \\
\text { wording bias. }\end{array}$ \\
\hline
\end{tabular}

\subsection{Data Analysis Method}

Variables affecting CEEDRW were ranked according to the weighted average and relative important index (RII). Weights in the Likert scale were assigned to quantify the 
inputs. Based on that, the variables were ranked. Finally, a principal component analysis was conducted to identify the relationship between the variables. RII was used to identify the significance of the variables. RII was calculated using the following Equation (1):

$$
\mathrm{RII}=\left(\sum \mathrm{w}\right) / \mathrm{AN},
$$

In which: $\mathrm{w}$ is the specific weight suggested by the respondents, $\mathrm{A}$ is the highest allocable weight, and $\mathrm{N}$ is the total number of respondents [56].

Once the factors are ranked, the data set should be tested for factor analysis. KaiserMeyer-Olkin (KMO) and Bartlett's test of sphericity is one of the tests that can be conducted to test whether a factor analysis is appropriate for a data set or not. A dataset should acquire a value above 0.5 and near 1.0 in the KMO test [57]. Data in Section 2 of the research acquired 0.768 , which was considered adequate for the research.

The selected factors are further scrutinised to remove insignificant factors using a scree plot or parallel analysis method. The scree plot uses a graph of the Eigenvalues to find change natural bend in data. Further, random order Eigenvalues were generated and compared with actual Eigenvalues. The factors are accepted if the actual Eigenvalues are higher than the random order Eigenvalues [58,59]. However, Williams et al. [58] and Henson and Roberts [60] justified that the parallel analysis method is a more reliable and consistent method for selecting the factors than a scree plot method. Therefore, a parallel analysis was used to remove insignificant factors.

\section{Results}

\subsection{Variables Considered in Past CEEDRW and to Be Considered in Future CEEDRW}

According to the study, F 09.1 (Changes required in reconstruction to meet statutory compliance) and F 01 (Consequential damage repair) were identified as the most commonly considered variables in damage estimates endorsed by more than $90 \%$ of respondents (refer to Figure 2). However, F 05.1 (damage from aftershocks), F 02.4a (Cost of lawyers' / advocates' legal services), and F $02.4 \mathrm{~b}$ (Cost of dispute resolution facilitators' / dispute resolvers' services) were considered by less than $50 \%$ in their CEEDRW. However, more than 60 percent of the participants agreed that these three variables should be considered in future CEEDRW.

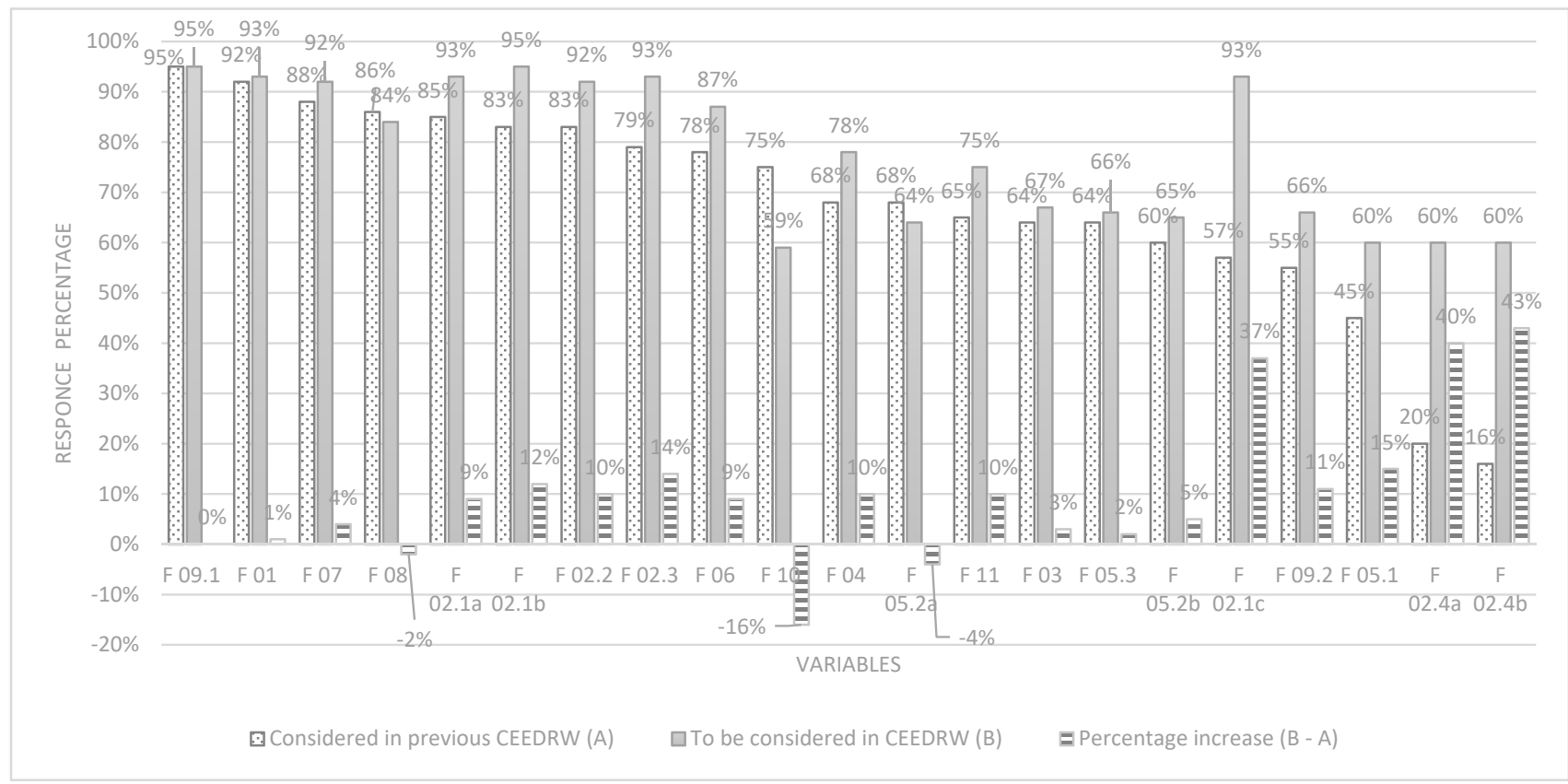

Figure 2. Comparison between variables that were considered in previous CEEDRW and variables that should be included CEEDRW. 
In addition, three variables show decreased approval to be included in future CEEDRW. These were F 08 (Initially unforeseen damage), F 10 (Pre-earthquake state of the building), and F 05.2a (Damage from earthquake-induced hazards-flood).

\subsection{Significance of These Variables on Cost}

According to the questionnaire survey, more than $50 \%$ of the participants considered these variables in their CEEDRW, except for F 05.1, F 02.4a and F 02.4b. However, these variables must be included in cost estimations based on the significance of their financial impact on CEEDRW.

Weighted averages and RII showed that F 09.1, F 02.1b, F 08 and F 01 had the highest significance with a weighted average above four and RII above 0.8 , respectively (refer to Table 5). Alternatively, F 03, F 09.2, F 05.1, F 05.3, F 05.2a, F 05.2b, F 02.4a, and F 02.4b had the lowest weighted averages with a weighted average below three, respectively. It also can be seen that F $02.4 \mathrm{~b}$ (Cost of dispute resolution facilitators' / dispute resolvers' services) gained the highest standard deviation and the lowest weighted average. However, three of the aforementioned lowest-rated variables, F 03, F 09.2, and F 05.1, had a slight negative skewness and weight average near three.

Table 5. Significance of the variables affecting CEEDRW according to the weighted average.

\begin{tabular}{|c|c|c|c|c|c|}
\hline Rank & Variables Affecting CEEDRW & $\begin{array}{l}\text { Percentage } \\
\text { Considered } \\
\text { in Past } \\
\text { CEEDRW }\end{array}$ & $\begin{array}{c}\text { Weighted } \\
\text { Average }\end{array}$ & RII & $\begin{array}{l}\text { Standard } \\
\text { Deviation }\end{array}$ \\
\hline 1 & F 02.1a-Cost of structural engineering services & $85 \%$ & 4.52 & 0.90 & 0.98 \\
\hline 2 & $\begin{array}{l}\text { F } 09.1 \text { - Changes required to final repair state- to meet } \\
\text { statutory compliance }\end{array}$ & $95 \%$ & 4.45 & 0.89 & 0.87 \\
\hline 3 & F $02.1 \mathrm{~b}-$ Cost of geotechnical engineering services & $83 \%$ & 4.27 & 0.85 & 1.04 \\
\hline 4 & F 08-Initially unforeseen damage & $86 \%$ & 4.22 & 0.84 & 1.15 \\
\hline 5 & F 01 - Consequential damage repair & $92 \%$ & 4.02 & 0.80 & 1.07 \\
\hline 6 & F 07-Duration of repairs & $88 \%$ & 3.84 & 0.77 & 1.13 \\
\hline 7 & $\begin{array}{l}\text { F 06-Price fluctuations due to change in demand for } \\
\text { resources caused by an earthquake }\end{array}$ & $78 \%$ & 3.82 & 0.76 & 1.19 \\
\hline 8 & F 02.2-Cost of architectural services & $83 \%$ & 3.74 & 0.75 & 1.22 \\
\hline 9 & F $02.1 \mathrm{c}-$ Cost of land surveying services & $57 \%$ & 3.73 & 0.75 & 1.17 \\
\hline 10 & F 11-Substandard initial repair work & $65 \%$ & 3.71 & 0.74 & 1.28 \\
\hline 11 & $\begin{array}{l}\text { F 04-Restrictions during repair (e.g., Building being } \\
\text { occupied during repair work) }\end{array}$ & $68 \%$ & 3.70 & 0.74 & 1.39 \\
\hline 12 & F 10-Pre-earthquake state of the building & $75 \%$ & 3.67 & 0.73 & 1.39 \\
\hline 13 & F 02.3 - Cost of quantity surveying services & $79 \%$ & 3.23 & 0.65 & 1.33 \\
\hline 14 & $\begin{array}{l}\text { F 03-Varying profit margins depending on the type of } \\
\text { building contract }\end{array}$ & $64 \%$ & 2.98 & 0.60 & 1.33 \\
\hline 15 & $\begin{array}{l}\text { F } 09.2 \text {-Changes required to final repair state- to meet } \\
\text { stakeholder requirements }\end{array}$ & $55 \%$ & 2.96 & 0.59 & 1.04 \\
\hline 16 & F 05.1-Damage from aftershocks & $45 \%$ & 2.78 & 0.56 & 1.16 \\
\hline 17 & F 05.3-Damage from weather conditions & $64 \%$ & 2.77 & 0.55 & 0.97 \\
\hline 18 & $\begin{array}{l}\text { F 05.2a-Damage from earthquake-induced } \\
\text { hazards-flood }\end{array}$ & $68 \%$ & 2.67 & 0.53 & 0.78 \\
\hline 19 & F $05.2 b$-Damage from earthquake-induced hazards—fire & $60 \%$ & 2.59 & 0.52 & 1.27 \\
\hline 20 & F 02.4a-Cost of lawyers' / advocates' legal services & $20 \%$ & 2.46 & 0.49 & 1.23 \\
\hline 21 & $\begin{array}{l}\mathrm{F} 02.4 \mathrm{~b}-\text { Cost of dispute resolution facilitators' / dispute } \\
\text { resolvers' services }\end{array}$ & $16 \%$ & 2.46 & 0.49 & 1.58 \\
\hline
\end{tabular}

\subsection{Exploratory Factor Analysis on the 21 Variables}

Based on the verification of the KMO test, exploratory factor analysis was conducted to identify similarities between the above variables and simplify them into groups. Principal component analysis (PCA) is one of the most common methods used for exploratory factor analysis [58]. PCA with Varimax rotation was used to analyse the data [61]. In the PCA 
method, underlying factors that account for most of the variance were identified. These factors can group the variables [60].

Kaiser [62] defined that factors with an Eigenvalue above one are the most impactful variables. Statistical analysis identified six main underlying factors impacting the 21 variables with Eigenvalue above one (Table 6). These six factors accounted for $66.875 \%$ of the total variance.

Table 6. Total variance.

\begin{tabular}{ccccccccc}
\hline & \multicolumn{2}{c}{ Initial Eigenvalues } & \multicolumn{2}{c}{ Extraction Sums of Squared Loadings } & \multicolumn{3}{c}{ Rotation Sums of Squared Loadings } \\
\hline \multirow{2}{*}{ Total } & $\begin{array}{c}\text { \% of } \\
\text { Variance }\end{array}$ & Cumulative \% & Total & $\begin{array}{c}\text { \% of } \\
\text { Variance }\end{array}$ & Cumulative \% & Total & $\begin{array}{c}\text { \% of } \\
\text { Variance }\end{array}$ & Cumulative \% \\
\hline 6.325 & 30.120 & 30.120 & 6.325 & 30.120 & 30.120 & 3.236 & 15.408 & 15.408 \\
2.213 & 10.537 & 40.657 & 2.213 & 10.537 & 40.657 & 2.892 & 13.771 & 29.179 \\
1.803 & 8.588 & 49.245 & 1.803 & 8.588 & 49.245 & 2.213 & 10.538 & 39.717 \\
1.434 & 6.830 & 56.075 & 1.434 & 6.830 & 56.075 & 2.060 & 9.810 & 49.527 \\
1.304 & 6.209 & 62.284 & 1.304 & 6.209 & 62.284 & 2.001 & 9.528 & 59.055 \\
1.073 & 5.108 & 67.392 & 1.073 & 5.108 & 67.392 & 1.751 & 8.337 & 67.392 \\
0.974 & 4.639 & 72.031 & & & & & & \\
0.852 & 4.057 & 76.088 & & & & & & \\
\hline
\end{tabular}

Table 7 summarises the parallel analysis done based on Eigenvalues to identify and remove the insignificant variables. According to Parallel Analysis, three of the six factors were acceptable. Based on the selected factors, a rotation component matrix was developed for the three factors identified. The rotation component matrix expresses the impact of three factors on the variables (refer to Table 8).

Table 7. Parallel analysis.

\begin{tabular}{ccccc}
\hline $\begin{array}{c}\text { Component } \\
\text { (Factor) }\end{array}$ & $\begin{array}{c}\text { Eigenvalues from } \\
\text { Actual Data Using } \\
\text { PCA (A) }\end{array}$ & $\begin{array}{c}\text { Random Order } \\
\text { Eigenvalues from } \\
\text { Parallel Analysis (B) }\end{array}$ & (A-B) & $\begin{array}{c}\text { Decision on } \\
\text { Factor }\end{array}$ \\
\hline 1 & 6.33 & 2.15 & 4.17 & Accepted \\
2 & 2.21 & 1.88 & 0.33 & Accepted \\
3 & 1.80 & 1.75 & 0.05 & Accepted \\
4 & 1.43 & 1.62 & -0.18 & Rejected \\
5 & 1.30 & 1.50 & -0.19 & Rejected \\
6 & 1.07 & 1.41 & -0.33 & Rejected \\
\hline
\end{tabular}

Table 8. Rotated component matrix.

\begin{tabular}{|c|c|c|c|c|c|c|}
\hline \multirow{2}{*}{ Variable } & \multicolumn{6}{|c|}{ Component } \\
\hline & F10 & F02 & F13 & F03 & F01 & F06 \\
\hline F 05.2b_-Damage from earthquake-induced hazards—fire & 0.902 & & & & & \\
\hline F 05.2a-Damage from earthquake-induced hazards-flood & 0.879 & & & & & \\
\hline F 05.3-Damage from weather conditions & 0.847 & & & & & \\
\hline F 05.1-Damage from aftershocks & 0.682 & & & & & \\
\hline F 02.1a-Cost of structural engineering services & & 0.859 & & & & \\
\hline F $02.1 \mathrm{~b}-$ Cost of geotechnical engineering services & & 0.838 & & & & \\
\hline F 02.2-Cost of architectural services & & 0.689 & & 0.463 & & \\
\hline F 02.3 - Cost of quantity surveying services & & 0.621 & & & 0.407 & \\
\hline F 02.1c-Cost of land surveying services & & 0.606 & & 0.424 & & \\
\hline F 10-Pre-earthquake state of the building & & & 0.696 & & & \\
\hline F 11-Substandard initial repair work & & & 0.666 & & & \\
\hline $\begin{array}{l}\text { F } 09.1-\text { Changes required to final repair state-to meet statutory } \\
\text { compliance }\end{array}$ & & & 0.631 & 0.380 & & \\
\hline F 08-Initially unforeseen damage & & & 0.526 & & & \\
\hline
\end{tabular}


Table 8. Cont.

\begin{tabular}{|c|c|c|c|c|c|c|}
\hline \multirow{2}{*}{ Variable } & \multicolumn{6}{|c|}{ Component } \\
\hline & F10 & F02 & F13 & F03 & F01 & F06 \\
\hline $\begin{array}{l}\text { F 06-Price fluctuations due to change in demand for resources as a } \\
\text { result of an earthquake }\end{array}$ & & & 0.417 & & & 0.382 \\
\hline F 04-Restrictions during repair & & & & 0.690 & & \\
\hline F 07-Duration of repairs & & & & 0.685 & & 0.405 \\
\hline F 01-Consequential damage repair & & & 0.428 & 0.567 & & \\
\hline F 02.4a-Cost of lawyers' / advocates' legal services & & & & & 0.881 & \\
\hline $\begin{array}{l}\text { F } 02.4 b-C o s t \text { of dispute resolution facilitators' / dispute resolvers' } \\
\text { services }\end{array}$ & & & & & 0.806 & \\
\hline $\begin{array}{l}\text { F 03-Varying profit margins depending on the type of building } \\
\text { contract }\end{array}$ & & & & & & 0.772 \\
\hline $\begin{array}{l}\text { F } 09.2 \text { - Changes required to final repair state - to meet stakeholder } \\
\text { requirements }\end{array}$ & & & & & & 0.694 \\
\hline
\end{tabular}

\section{Discussion}

Current probability-based cost estimation models like PACT, SLAT, HAZUS and, SP3 only consider three of the eleven variables considered in this research. These are damage from aftershocks, floods and fires; restrictions during repair; and initially unforeseen damage [21]. Based on the results from Section 1, almost all of the variables were included in post-earthquake CEEDRW by more than $50 \%$ of the participants. In addition, all variables were suggested to include in future usage by more than $60 \%$ of the participants.

However, aftershocks (F 05.1), cost of lawyers' / advocates' legal services (F 02.4a), and cost of dispute resolution facilitators' / dispute resolvers' services (F 02.4b) had less than $50 \%$ approval rating in past usage. The main reason for not including the damage from aftershocks in the CEEDRW could be because of a court ruling. Wellington high court [34] ruled that subsequent natural disaster events like aftershocks should be considered as new events. A separate evaluation should be conducted for each. In additional cost of legal and dispute resolution services would apply in specific situations when legal counsel or dispute services are required. Therefore, the CEEDRW process would only include them when required. However, these costs can have a substantial impact on CEEDRW [21]. Therefore, it can be justified that all variables were considered by a past CEEDRW when required. In addition, all three variables gained an approval rating above 60 percent for future usage.

In addition, three variables had a reduction in future usage. A significant reduction of 16 percent was for pre-earthquake damage (F 10). Most of the pre-earthquake damage is not typically considered by earthquake damage-related repair work, which was funded by insurance claims. This major portion of repair work is related to CEQS, as $52 \%$ of total loss can be attributed to insurance claims [3]. Therefore, most CEEDRW processed would exclude pre-earthquake damage.

Furthermore, initially unforeseen damage (F 08) and damage from earthquake-induced floods (F 05.1a) also had a decrease in future usage. These types of damage were considered variations in the New Zealand context, and traditional CEEDRW processes would exclude these costs until identified. Therefore, the reduction in future usage of the three variables mentioned above is logical. However, a tool built for post-earthquake CEEDRW should include the impact of these variables.

The significance of these variables on CEEDRW was identified in Section 2. Variable F 09.1 (Changes required in reconstruction to meet statutory compliance) was the most significant variable with a weighted average of 4.45 . All repair work should comply with changes to the building code. After the CEQS, many changes to the building code were introduced, resulting in changes to the scope of repair. Changes in building code resulted in additional work beyond the scope and disagreements with regard to changes. Since these changes are unpredictable and can have an impact on all damaged buildings, results are justifiable. 
Additionally, F 03, F 09.2, F 05.1, F 05.3, F 05.2a, F 05.2b, F 02.4a, and F 02.4b gained a weighted average below 3 . Reasons for the low significance of these variables can be justified as follows. Most of the cost estimations have a defined scope. Any changes to the scope will update the cost estimate [63]. Therefore, changes required in reconstruction to meet stakeholder requirements (F 09.2) will be considered as variations when it occurs [25]. This is similar to the cost of legal and dispute resolution services. Therefore, the low significance by the respondents for the variable changes required in reconstruction to meet stakeholder requirements (F 09.2) is justifiable.

Damage from aftershocks (F 05.1), flood (F 05.2a), fire (F 05.2b), weather conditions (F 05.3) gained a low importance level. In New Zealand, the court ruling decided that these events were considered separate events caused by the earthquake and were considered variations [34]. Therefore, separate cost estimations were developed once these damages occur and were not included in initial cost estimations.

According to a New Zealand court case in Christchurch, the maximum profit margin (F 03) used in CEEDRW was identified as 10 percent [27]. Open-ended questions revealed that the earthquake commission (EQC) selected the builders using a schedule of rates. This method prevented extreme fluctuation, creating a low overall impact from changes in profit margin. Hence the significance of varying profit margins was low after CEQS. Based on the above justifications, the low importance of the F 03, F 09.2, F 05.1, F 05.3, F 05.2a, F 05.2b, F 02.4a, and F 02.4b is acceptable. However, these justifications were specific to New Zealand and can be different in earthquake events occurring in other regions.

Principal component analysis with Varimax rotation conducted on the variables yielded six underlying factors, which was reduced to three parallel analysis factors. These three underlying factors that impact most of the identified variables impacting CEEDRW can be defined as earthquake damage amplifiers, architectural and engineering service costs, and complexities and indirect earthquake influences.

\subsection{Earthquake Damage Amplifiers}

Earthquake damage amplifiers achieved $30.1 \%$ of the variances and contained four variables (F 05.1, F 05.2a, F 05.2b, and F 05.3). Fire, flood, and aftershocks are earthquakeinduced hazards [29]. Earthquake-induced land level changes can cause inundations. Furthermore, sudden damage to building elements can also trigger fires. Weather damage to a building can also occur due to an earthquake's external building fabric and foundations being compromised.

A high court case in New Zealand noted that these forms of damage could be considered separate earthquake events if they occur after the main earthquake but are caused by the earthquake [34]. Damage for these amplifiers is unique to other variables. However, a standard cost estimation method could be developed to estimate their cost impact.

\subsection{Architectural and Engineering Service Costs}

Architectural and engineering service costs achieved $10.5 \%$ of the variance and contained five variables (F 02.1a, F 02.1b, F 02.1c, F 02.2, F 02.3, F 02.4a, F 02.4b). The structural engineer, geotechnical engineer, architect, quantity surveyor, and land surveyor are all professional service costs categorised into one group based on the architectural and engineering service costs factor. These costs are all typically required for construction projects.

Professional fees for lawyers and dispute resolution facilitators have less significance in CEEDRW. These two professional services are required when a dispute or negotiation situation occurs. Since they are not needed for all projects, their cost was not included in this group.

Since most projects require architectural and engineering service, a standard cost inclusion method could be developed for architectural and engineering service cost calculations. 


\subsection{Complexities and Indirect Earthquake Influences}

Complex and indirect earthquake influences specific to CEEDRW consist of $8.6 \%$ of the variance and contain six variables (F 01, F 06, F 08, F 09.1, F 10, and F11).

Consequential damages (F 01) are caused by interconnected elements and are typically identified during repair work. To determine the cost of these damages at an early stage, each repair work process must be simulated. The simulations require extensive details of; interconnected building elements, damage to elements, repair methods, and step-by-step repair processes. Within the limited time frame available for CEEDRW, it is difficult to identify the compounded impact of consequential damages using the aforementioned details.

Initially unforeseen damage (F 08) is also a complex variable to predict as the information required to identify damage is hidden. Therefore, more intrusive damage identification methods or complex damage prediction methods should be used to identify damage at the initial stages.

An imbalance between supply and demand creates price fluctuation induced by an earthquake (F 06). Stephenson [64] states that cost escalation can be attributed to the deviations in demand compared to the labour supply, buyers' preparedness to pay higher costs and wages to obtain skilled labour from other regions. There is research on estimating price fluctuations caused by disasters $[38,39,65]$. However, due to its complex nature, there was no evidence of practical applications.

It is also difficult to predict changes required to the final repair state to meet statutory compliances (F 09.1) as there can be building code changes influenced by an earthquake. For example, the 2011 Canterbury earthquake and the 2016 Kaikoura earthquake triggered many building code changes in New Zealand [66].

Pre-earthquake damage (F 10) and substandard initial repair work (F 11) are related to earthquake damage repair work and are difficult to identify. Pre-earthquake damage is especially identified during CEEDRW as they are not considered as part of the earthquake damage repair funded by insurers [49]. Alternatively, substandard repair work was identified after the CEQS [50,51], which made the repair process difficult by covering earthquake damage and led to secondary repair work. These variables can hide earthquake damage, and specific damage identification processes might be required to identify earthquake damage increasing the complexity. Hence, these six variables can be categorised as complexities and indirect earthquake influences. The six variables related to this factor will be most difficult to predict during CEEDRW as they are both complex and specific to earthquake damage repair work.

Since the importance and significance of these eleven variables have been identified, the aforementioned variables can be used to develop an accurate post-earthquake cost estimation model. Alternatively, probability-based tools like HAZUS, PACT, SLAT and SP3 currently do not consider the impact of all aforementioned eleven variables in the cost estimation process. Therefore, further research can be conducted to identify methods that can be used to include the impact of these variables in these probability-based tools.

\section{Conclusions}

In conclusion, eleven significant variables (which consists of 21 subvariables) that impacted post-earthquake cost estimations for earthquake damage repair work were considered by this research. The research identified that all variables were considered past post-earthquake cost estimations and a higher number of participants are willing to consider these variables in future cost estimations. Based on the significance, the most critical variables are; changes required to the final repair state to meet statutory compliance, initially unforeseen damage and consequential damage repair.

Three main components contributed to the majority of the variances of these variables. These variables have been identified as earthquake damage amplifiers, architectural and engineering services costs, and complexities and indirect earthquake influences. A typical cost impact assessment method could be developed for the variables in each category. However, the practicality of such methods should be further researched. Furthermore, 
these variables can be used to develop an accurate post-earthquake cost estimation model and improve current probability-based earthquake damage prediction tools.

The findings of this research are subject to some limitations. The participants in this research mainly had experience in New Zealand and specifically in one earthquake. Therefore, the variables discussed in this paper could vary in other parts of the world and different scenarios. Further research is also required to quantify the impact of these variables. Quantified implications of the variables can be used to develop post-earthquake cost estimation tools and improve the forecasting ability of pre-earthquake estimation tools.

Furthermore, there are potential sources of bias impacting this research. Participants of the study were voluntary, specialised and contacted based on their ability to find their contact details. Therefore, the research suffers from voluntary bias, selection bias and convivence bias. Wording bias caused by inaccurate wording or leading questions were reduced through the pilot survey. The research also suffers from response bias because the participants give inaccurate data. The response bias related to this research is acquiescent because participants tend to provide positive feedback and due to participants' tendency to answer the question.

Author Contributions: Individual contributions of the authors are as follows: Conceptualisation, R.K.A.V.D.K. and N.D.D.; methodology, R.K.A.V.D.K. and N.D.D.; validation, R.K.A.V.D.K. and N.D.D.; formal analysis, R.K.A.V.D.K.; investigation, R.K.A.V.D.K. and N.D.D.; resources, R.K.A.V.D.K., N.D.D., G.C. and S.R.U.; data curation, R.K.A.V.D.K.; writing—original draft preparation, R.K.A.V.D.K.; writing-review and editing, R.K.A.V.D.K., N.D.D., G.C. and S.R.U.; visualisation, R.K.A.V.D.K., N.D.D. and G.C.; supervision, N.D.D., G.C. and S.R.U.; project administration, R.K.A.V.D.K., N.D.D., G.C. and S.R.U. All authors have read and agreed to the published version of the manuscript.

Funding: This research received no external funding.

Institutional Review Board Statement: This research and data collection process was also approved by the Massey University Human Ethics Committee: Northern (Application 4000017232).

Informed Consent Statement: Informed consent was obtained from all subjects involved in the study.

Data Availability Statement: Restrictions apply to the availability of research data as researchers agreed with the study participants not to share their data. However, summarised data presented in this study are available on request from the corresponding author.

Acknowledgments: The authors would like to thank all organisations and expert interviewees who supported and were involved in this research. Special acknowledgments go to James Dawson, Nishadi Sooriyamudalige, Ester Aigwi, Janitha Jayadeva, Chinthaka Atapattu, and Greg Preston for providing comments and helping with data collection.

Conflicts of Interest: The authors declare no conflict of interest. 


\section{Appendix A}

$8 / 20 / 2021$

\section{Factors affecting the repair costs of earthquake damaged buildings}

Please enter a valid email for unique coding purposes.

* Required

1. Email *

\section{Project Description}

This survey focuses on identifing the factors that affect the repair costs of earthquake damaged buildings. This survey forms part of my $\mathrm{PhD}$ research project that aims to develop a model to calculate repair costs of earthquake damaged buildings. The outcome of the research will help builders prepare more accurate cost estimates.

Project Procedures and Data Management

The survey will take around 10 minutes to complete. Data will be stored securely under strict access and password protection. Access to this information is only available to the researcher and supervisors. The data will be stored in a desktop computer and secure cloud storage. The project findings will be published in conferences and journals. The participants will be notified of the publications upon request.

Committee Approval Statement

This research has been reviewed and approved by the Massey University Human Ethics Committee: Northern, Application 4000017232. If you have any concerns about the conduct of this research, please contact A/Prof David Tappin, Chair, Massey University Human Ethics Committee: Northern, telephone 6494140800 x 43384 email humanethicsnorth@massey.ac.nz.

\section{Participant consent}

2. Do you wish to be a participant in this research? *

Mark only one oval.

Yes (which means you give consent to become a participant)

No

Brief overview of your experience

Please choose the most relevent responce

Figure A1. Questionnaire design (sample 1). 
$8 / 20 / 2021$

Factors affecting the repair costs of earthquake damaged buildings

3. Do you have experience in assessing the repair cost of earthquake damaged buildings? *

Mark only one oval.
Yes
No

4. If yes, please state the years of experience in earthquake damage repair work estimation. *

Factors that affect the repair costs of earthquake damaged buildings

Figure A2. Questionnaire design (sample 2). 
5. Please select from the following list the factors you considered when assessing the repair cost of earthquake damaged buildings. *

Mark only one oval per row.

\begin{tabular}{|c|c|c|}
\hline & Yes & No \\
\hline $\begin{array}{l}\text { Price fluctuations due to change in demand } \\
\text { for resources as a result of an earthquake } \\
\text { (e.g. changes in Labour rates due to high } \\
\text { demand) }\end{array}$ & & \\
\hline $\begin{array}{l}\text { Initially unforeseen damage (e.g. structural } \\
\text { damage identified during construction) }\end{array}$ & & \\
\hline $\begin{array}{l}\text { Duration of repairs (e.g. preliminary and time } \\
\text { related costs depend on repair duration) }\end{array}$ & & \\
\hline $\begin{array}{l}\text { Building being occupied during repair work } \\
\text { (e.g. restriction on repair time and access) }\end{array}$ & & \\
\hline Substandard initial repair work & & \\
\hline $\begin{array}{l}\text { Damage from aftershocks (e.g. tremors that } \\
\text { occur after the earthquake might increase } \\
\text { building damage) }\end{array}$ & & \\
\hline
\end{tabular}

Damage from weather conditions (e.g. rain, wind and snow can increase the damage of buildings)

Changes required in reconstruction to meet statutory compliance

Changes required in reconstruction to meet client requirements (e.g. improvements in the structure)

Pre-earthquake state of the building (e.g. damage that had occurred before the earthquake, ground subsidence)

Impact of a damaged building element on another adjoining building element (e.g. damage of a partition wall which is in contact with a ceiling and associated cornices)

Varying profit margins depending on the type of building contract (e.g. lump sum, cost plus margin etc.)

Figure A3. Questionnaire design (sample 3). 
$8 / 20 / 2021$

Factors affecting the repair costs of earthquake damaged buildings

8. Please indicate significance of the following factors on accuracy of the repair cost estimates of earthquake damaged buildings. *

Mark only one oval per row.

\begin{tabular}{|c|c|c|c|c|c|}
\hline & $\begin{array}{c}\text { Very } \\
\text { Important }\end{array}$ & Important & $\begin{array}{c}\text { Some } \\
\text { importance }\end{array}$ & $\begin{array}{l}\text { Slightly } \\
\text { important }\end{array}$ & $\begin{array}{l}\text { Not } \\
\text { important } \\
\text { at all }\end{array}$ \\
\hline $\begin{array}{l}\text { Price fluctuations as a } \\
\text { result of post- } \\
\text { earthquake demand }\end{array}$ & & & & & \\
\hline Unforeseen damage & & & & & \\
\hline Duration of works & & & & & \\
\hline $\begin{array}{l}\text { Building being occupied } \\
\text { during repair work }\end{array}$ & & & & & \\
\hline $\begin{array}{l}\text { Varying profit margins } \\
\text { depending on the type of } \\
\text { building contract }\end{array}$ & & & & & \\
\hline $\begin{array}{l}\text { Damage as a result of } \\
\text { aftershocks }\end{array}$ & & & & & \\
\hline $\begin{array}{l}\text { Damage as a result of } \\
\text { flood }\end{array}$ & & & & & \\
\hline $\begin{array}{l}\text { Damage as a result of } \\
\text { fire }\end{array}$ & & & & & \\
\hline $\begin{array}{l}\text { Damage as a result of } \\
\text { rain, wind and snow }\end{array}$ & & & & & \\
\hline $\begin{array}{l}\text { Changes required in } \\
\text { reconstruction to meet } \\
\text { statutory compliance }\end{array}$ & & & & & \\
\hline $\begin{array}{l}\text { Changes required in } \\
\text { reconstruction to meet } \\
\text { client requirements }\end{array}$ & & & & & \\
\hline $\begin{array}{l}\text { Pre-earthquake state of } \\
\text { the building }\end{array}$ & & & & & \\
\hline $\begin{array}{l}\text { Impact of a damaged } \\
\text { building element on } \\
\text { another ajoining building } \\
\text { element (e.g. damage of }\end{array}$ & & & & & \\
\hline
\end{tabular}

https://docs.google.com/forms/d/1YKvNcRTcW76tZMK_x_girEB7VXiX4qwL2P8rrts0Egw/edit

Figure A4. Questionnaire design (sample 4). 


\section{References}

1. Munich Re Group. Earthquake/Tsunami Events Worldwide 1980-2018; Munich Re Group: München, Germany, 2020.

2. Horspool, N.A.; King, A.B.; Lin, S.L.; Uma, S.R. Damage and losses to residential buildings during the Canterbury earthquake sequence. Proc. N. Z Soc. Earthq. Eng. 2016. Available online: https://www.nzsee.org.nz/db/2016/Papers/O-04\%20Horspool. pdf (accessed on 20 May 2021).

3. ICNZ Canterbury Earthquakes. Available online: https://www.icnz.org.nz/natural-disasters/canterbury-earthquakes / (accessed on 27 October 2019).

4. Applied Technology Council. Seismic Performance Assessment of Buildings, Volume 1-Methodology, 2nd ed.; Applied Technology Council: Redwood City, CA, USA, 2018; Volume 1.

5. FEMA. HAZUS-MH MR4 Technical Manual; FEMA: Washington, DC, USA, 2003.

6. HaseltonBaker Risk Group. Seismic Risk Assessment Report-Full Detailed Report. 2020. Available online: https://sp3risk.com/ sp3-riskmodel/ (accessed on 20 May 2021).

7. Molina, S.; Lang, D.H.; Lindholm, C.D. SELENA-An open-source tool for seismic risk and loss assessment using a logic tree computation procedure. Comput. Geosci. 2010, 36, 257-269. [CrossRef]

8. Applied Technology Council. PACT 3.1.2—Software; Applied Technology Council: Redwood City, CA, USA, 2018.

9. Applied Technology Council. Seismic Performance Assessment of Buildings, Volume 2-Implementation Guide, 2nd ed.; Applied Technology Council: Redwood City, CA, USA, 2018; Volume 2.

10. Bradley, B.A. User Manual for SLAT: Seismic Loss Assessment Tool Version 1.14; Department of Civil Engineering, University of Canterbury: Christchurch, New Zealand, 2009.

11. Charalambos, G.; Dimitrios, V.; Symeon, C. Damage Assessment, Cost Estimating, and Scheduling for Post-Earthquake Building Rehabilitation Using BIM. In Computing in Civil and Building Engineering; American Society of Civil Engineers: Orlando, FL, USA, 2014; pp. 398-405.

12. Vona, M.; Mastroberti, M.; Mitidieri, L.; Tataranna, S. New resilience model of communities based on numerical evaluation and observed post seismic reconstruction process. Int. J. Disaster Risk Reduct. 2018, 28, 602-609. [CrossRef]

13. Jiao, Q.; Jiang, H.; Li, Q. Building Earthquake Damage Analysis Using Terrestrial Laser Scanning Data. Adv. Civ. Eng. 2019, 2019, 1-12. [CrossRef]

14. Kahandawa, R.; Domingo, N.D.; Park, K.S.; Uma, S.R. Earthquake damage estimation systems: Literature review. Procedia Eng. 2018, 212, 622-628. [CrossRef]

15. Applied Technology Council. Seismic Performance Assessment of Buildings Volume 1-Methodology (FEMA P-58-1); Applied Technology Council: Washington, DC, USA, 2012; Volume FEMA, p. 58.

16. Memon, A.H.; Rahman, I.A.; Abdullah, M.R.; Azis, A.A.A. Factors affecting construction cost in Mara Large Construction Project: Perspective of project management consultant. Int. J. Sustain. Constr. Eng. Technol. 2010, 1, 41-54.

17. Olawale, Y.A.; Sun, M. Cost and time control of construction projects: Inhibiting factors and mitigating measures in practice. Constr. Manag. Econ. 2010, 28, 509-526. [CrossRef]

18. Frimpong, Y.; Oluwoye, J.; Crawford, L. Causes of delay and cost overruns in construction of groundwater projects in a developing countries; Ghana as a case study. Int. J. Proj. Manag. 2003, 21, 321-326. [CrossRef]

19. Rahman, I.A.; Mem, A.H.; Karim, A.T.A. Significant factors causing cost overruns in large construction projects in Malaysia. J. Appl. Sci. 2013, 13, 286-293. [CrossRef]

20. Kim, S.Y.; Tuan, K.N.; Do Lee, J.; Pham, H.; Luu, V.T. Cost overrun factor analysis for hospital projects in Vietnam. KSCE J. Civ. Eng. 2018, 22, 1-11. [CrossRef]

21. Kahandawa, R.; Domingo, N.; Chawynski, G.; Uma, S.R. Factors impacting post-earthquake damage repair cost estimations. Int. J. Disaster Resil. Built Environ. 2020. [CrossRef]

22. Dhakal, R.P. Damage to non-structural components and contents in 2010 Darfield earthquake. Bull. N. Z. Soc. Earthq. Eng. 2010, 43, 404-411. [CrossRef]

23. BRANZ. Learnings from the Canterbury Earthquakes; BRANZ: Porirua, New Zealand, 2012.

24. Di Ludovico, M.; Prota, A.; Moroni, C.; Manfredi, G.; Dolce, M. Reconstruction process of damaged residential buildings outside historical centres after the L'Aquila earthquake: Part II-“'heavy damage” reconstruction. Bull. Earthq. Eng. 2017, 15, 693-729. [CrossRef]

25. Brook, M. Estimating and Tendering for Construction Work. [Electronic Resource], 5th ed.; Routledge, Taylor and Francis Group: Abingdon, UK, 2017; ISBN 9781317561736.

26. Paul Geoffrey Myall vs Tower Insurance Ltd.; 2017; CIV-2015-409-000230 [2017] NZHC 251. Available online: https: //forms.justice.govt.nz/search/Documents/pdf/jdo/51/alfresco/service/api/node/content/workspace/SpacesStore/27f7 56f8-1c8a-429a-9917-73aa3c6324b6/27f756f8-1c8a-429a-9917-73aa3c6324b6.pdf (accessed on 20 May 2021).

27. Duncan Cotterill. Judgment Summary-Paul Geoffrey Myall V Tower Insurance Ltd. [2017] NZHC 251; 2017. Available online: https:/ / duncancotterill.com/publications/judgment-summary-paul-geoffrey-myall-v-tower-insurance-ltd-2017-nzhc251 (accessed on 20 May 2021).

28. Ward, A.E.; Azhar, S.; Khalfan, M. Construction in Occupied Spaces. Slovak J. Civ. Eng. 2017, 25, 15-23. [CrossRef]

29. Jia, J. Earthquake damages. In Modern Earthquake Engineering; Springer: Berlin/Heidelberg, Germany, 2017; pp. 413-431. ISBN 978-3-642-31853-5. 
30. Inland Marine Underwriters Association. Builders Risk Guide to Loss Prevention Part Two: Water Related Exposures; Inland Marine Underwriters Association: New York, NY, USA, 2001.

31. Potter, S.H.; Becker, J.S.; Johnston, D.M.; Rossiter, K.P. An overview of the impacts of the 2010-2011 Canterbury earthquakes. Int. J. Disaster Risk Reduct. 2015, 14, 6-14. [CrossRef]

32. Baker, G.B.; Collier, P.C.R.; Abu, A.K.; Houston, B.J. Post-Earthquake Structural Design for Fire-A New Zealand Perspective. Eng. Conf. Contrib. 2012. [CrossRef]

33. Davis, C.A.; Giovinazzi, S.; Hart, D.E. Liquefaction Induced Flooding in Christchurch New Zealand. In Proceedings of the 6th International Conference on Earthquake Geotechnical Engineering, Christchurch, New Zealand, 1-4 November 2015.

34. Tower Insurance Ltd V Earthquake Commission. 2011, p. CIV-2011-485-1116. Available online: https:/ / www.interest.co.nz/sites / default/files / Earthquake\%20Commission-1.pdf (accessed on 20 May 2021).

35. Döhrmann, D.; Gürtler, M.; Hibbeln, M. Insured loss inflation: How natural catastrophes affect reconstruction costs. J. Risk Insur. 2017, 84, 851-879. [CrossRef]

36. Statistics New Zealand Labour Cost Index-Median and Mean Increase by Industry \& Location. Available online: https: //www.stats.govt.nz/ (accessed on 1 January 2021).

37. Perdia, S.; McNaughton, A. Post-Earthquake Price Dynamics in Christchurch/Canterbury; Canterbury Development Corporation: Christchurch, New Zealand, 2014.

38. Khodahemmati, N. Diagnosis and Quantification of Post-Disaster Construction Material Cost Fluctuations. Univ. Tex. Arlington 2018. Available online: https://www.researchgate.net/publication/340805007_Diagnosis_and_Quantification_of_Postdisaster_ Construction_Material_Cost_Fluctuations (accessed on 20 May 2021).

39. Ahmadi, N.; Shahandashti, S.M. Role of predicate construction market conditions in influencing post disaster demand surge. Nat. Hazards Rev. 2018, 19, 1-13. [CrossRef]

40. Chang, Y.; Wilkinson, S.; Seville, E.; Potangaroa, R. Changes in resource need for post-disaster reconstruction: A longitudinal study in China. Build. Res. Inf. 2012, 40,327-336. [CrossRef]

41. Almufti, I.; Willford, M.; Delucchi, M.; Davis, C.; Hanson, B.; Langdon, D.; Friedman, D.; Johnson, L.; Nielsen, G.; Riordan, N.O.; et al. REDi Rating System. Available online: Publications.arup.com/publications/r/redi_rating_systemtions (accessed on 27 March 2017).

42. Khosrowshahi, F.; Kaka, A.P. Estimation of project total cost and duration for housing projects in the U.K. Build. Environ. 1996, 31, 373-383. [CrossRef]

43. Clifton, C.; Bruneau, M.; MacRae, G.; Leon, R.; Fussell, A. Steel structures damage from the Christchurch earthquake series of 2010 and 2011. Bull. N. Z. Soc. Earthq. Eng. 2011, 44, 297-318. [CrossRef]

44. Galloway, B.D.; Hare, H.J. A review of post-earthquake building control policies with respect to the recovery of the Christchurch CBD. Bull. N. Z. Soc. Earthq. Eng. 2012, 45, 105-116. [CrossRef]

45. Robertson, G.; Woods, M. Resolution for Canterbury Owners of On-Sold Homes. Available online: https://www.beehive.govt. $\mathrm{nz} /$ release/resolution-canterbury-owners-sold-homes (accessed on 4 November 2019).

46. Doloi, H.; Sawhney, A.; Iyer, K.C.; Rentala, S. Analysing factors affecting delays in Indian construction projects. Int. J. Proj. Manag. 2012, 30, 479-489. [CrossRef]

47. Gebrehiwet, T.; Luo, H. Analysis of delay impact on construction project based on RII and Correlation Coefficient: Empirical study. Procedia Eng. 2017, 196, 366-374. [CrossRef]

48. Sohu, S.; Abd Halid, A.; Nagapan, S.; Fattah, A.; Latif, I.; Ullah, K. Causative factors of cost overrun in highway projects of Sindh province of Pakistan. IOP Conf. Ser. Mater. Sci. Eng. 2017, 271. [CrossRef]

49. Chawynski, G. Preparing expert witness documents to support earthquake affected insurance policy holders in Christchurch, New Zealand. J. Build. Surv. Apprais. Valuat. 2019, 5, 362-368.

50. Cretney, R. "An opportunity to hope and dream": Disaster politics and the emergence of possibility through community-led recovery. Antipode 2019, 51, 497-516. [CrossRef]

51. Price, S.; Peters, T. New Zealand: Substandard Repairs to Earthquake-Damaged Homes in Christchurch. Available online: http:/ / www.wsws.org (accessed on 4 November 2019).

52. Kahandawa, R.; Domingo, N.; Chawynski, G.; Uma, S.R. Factors Affecting Post-Earthquake Damage Repair Cost Estimations. Available online: https: / ir.canterbury.ac.nz/bitstream/handle/10092/17186/POSTER-Kahandawa_Investigation_into_the_ Factors_Affecting_Costs_of_Earthquake_Damage_Repair_Work.pdf?sequence=1\&isAllowed=y (accessed on 16 October 2019).

53. Bryman, A.; Bell, E. Business Research Methods, 3rd ed.; Oxford University Press: Oxford, UK, 2011 ; ISBN 9788578110796.

54. Neuman, W.L. Social Research Methods: Qualitative and Quantitative Approaches, 7th ed.; Pearson Education Limited: Essex, UK, 2014; ISBN 9781292020235.

55. Saunders, M.; Lewis, P.; Thornhill, A. Research Methods for Business Students, 8th ed.; Pearson Education: Harlow, UK, 2019; ISBN 9781292016627.

56. Iyer, K.C.; Jha, K.N. Factors affecting cost performance: Evidence from Indian construction projects. Int. J. Proj. Manag. 2005, 23, 283-295. [CrossRef]

57. Kaiser, H.F. An index of factorial simplicity. Psychometrika 1974, 39, 31-36. [CrossRef]

58. Williams, B.; Onsman, A.; Brown, T. Exploratory factor analysis: A five-step guide for novices. Australas. J. Paramed. 2010, 8, 1-13. [CrossRef] 
59. Hayton, J.C.; Allen, D.G.; Scarpello, V. Factor retention decisions in Exploratory Factor Analysis: A tutorial on Parallel Analysis. ORM Artic. Interest 2004, 7, 191-205. [CrossRef]

60. Henson, R.K.; Roberts, J.K. Use of Exploratory Factor Analysis in published research. Educ. Psychol. Meas. 2006, 66, 393-416. [CrossRef]

61. Costello, A.B.; Osborne, J.W. Best practices in exploratory factor analysis: Four recommendations for getting the most from your analysis. Pract. Assess. Res. Eval. 2005, 10. [CrossRef]

62. Kaiser, H.F. The application of electronic computers to Factor Analysis. Educ. Psychol. Meas. 1960, 20, 141-151. [CrossRef]

63. Flanagan, R.; Jewell, C. New Code of Estimating Practice; John Wiley \& Sons, Ltd.: Chichester, UK, 2018 ; ISBN 9781119329671.

64. Stephenson, J. Labour Cost Escalation in Canterbury; New Zealand Institiue of Economic Research: Wellington, New Zealand, 2013.

65. Olsen, A.H.; Porter, K.A. Storm surge to demand surge: Exploratory study of hurricanes, labor wages, and material prices. Nat. Hazards Rev. 2013, 14, 247-257. [CrossRef]

66. Nwadike, A.N.; Wilkinson, S. Building Code Amendment Process: A case study of New Zealand. In Proceedings of the 9th International Conference on Building Resilience-ICBR, Bali, Indonesia, 13-15 January 2020. 